\title{
Carbon dioxide sequestration in power plant Ca-rich ash waste deposits
}

\author{
Kristjan Leben ${ }^{(\mathrm{a})}$, Riho Mõtlep ${ }^{(\mathrm{a})}$, Alar Konist ${ }^{(\mathrm{b})}$, Tõnu Pihu ${ }^{(\mathrm{b})}$, \\ Kalle Kirsimäe $e^{(a)}$
}

(a) Department of Geology, University of Tartu, Ravila 14A, 50411 Tartu, Estonia

(b) Department of Energy Technology, Tallinn University of Technology, Ehitajate tee 5, 19086 Tallinn, Estonia

Received 22 July 2020, accepted 25 January 2021, available online 10 March 2021

\begin{abstract}
In order to reach future goals of net carbon neutrality and climate change mitigation, various carbon capture and sequestration techniques must be implemented. Industrial waste rich in chemically active alkaline metal oxides is considered as a potential material for $\mathrm{CO}_{2}$ sequestration. The authors studied the long-term $\mathrm{CO}_{2}$ binding capacity of Ca-rich oil shale ash (OSA) deposits at oil shale(OS)-fired power plants of Estonia and estimated the remaining sequestration potential for in-situ carbonation. Providing energy security, the Estonian oil shale industry is the biggest national producer of solid waste and the leading greenhouse gas emitter, making the country one of the largest per capita producers of $\mathrm{CO}_{2}$ in Europe. The study shows that ash deposits are currently only partially carbonated, with an average $\mathrm{CO}$, binding rate of $51 \mathrm{~kg}$ per tonne of hydrated sediment, most of which being bound in such carbonate minerals as calcite and vaterite, as well as in Ca-silicate thaumasite. It is estimated that at full carbonation of reactive $\mathrm{Ca}$ and $\mathrm{Mg}$ phases in ash (portlandite, ettringite and semicrystalline $C-S-H$ ), the projected average total $\mathrm{CO}_{2}$ binding potential could rise to ca $200 \mathrm{~kg}$ per tonne of ash.
\end{abstract}

Keywords: mineral carbonation, oil shale ash, ash utilisation, $\mathrm{CO}_{2}$ sequestration.

\section{Introduction}

In the light of current European $\mathrm{CO}_{2}$-trade policies and more importantly the long-term planning to achieve future climate goals (e.g. as stated in the Paris Agreement [1]), it is unavoidable that the usage of such fossil fuels as oil, coal, lignite and oil shale (OS) will diminish in coming decades. However, a carbon neutral economy can be realized by 2050 [2] only if we consider and apply all means capable of effectively reducing $\mathrm{CO}_{2}$ budget, including the implementation and optimization of various $\mathrm{CO}_{2}$ sequestration techniques.

\footnotetext{
*Corresponding author: e-mail kristjan.leben@ut.ee

(C) 2021 Authors. This is an Open Access article distributed under the terms and conditions of the Creative Commons Attribution-NonCommercial 4.0 International License (http://creativecommons.org/licenses/by-nc/4.0/).
} 
Different options that could help mitigate climate change, including carbon capture and storage (CCS), are already being considered worldwide. Several methods have been examined for CCS [3-8]. First, carbon dioxide can be deposited underground in suitable rock formations, dissolved in saline aquifers or adsorbed onto the organic matter in coal or shale formations. Underground deposition of $\mathrm{CO}_{2}$ is already widely used for enhanced oil recovery (EOR) to increase oil yields by increasing pressure and lowering oil viscosity. However, it requires the geological formation to have specific properties. For example, to ensure the stability of storage and minimize the possibility of $\mathrm{CO}_{2}$ being released back into the atmosphere, there must be an impermeable cap rock layer, available pore space and no fracturing or structural faults. In addition, the process requires sufficient burial depth, usually exceeding 800 meters, which provides enough pressure and temperature for achieving the supercritical state and decreases the volume of deposited $\mathrm{CO}_{2}$. Further questions related to this method include reliable assessment of storage site capacity as well as monitoring and detecting any possible leaks after storage [3]. However, when the method is used in EOR, the additional oil obtained during the process is likely to nullify any mitigation of the effect of the deposited $\mathrm{CO}_{2}$.

Another CCS method involves binding carbon dioxide in geologically stable carbonate minerals, i.e. mineral carbonation, which occurs naturally during the slow weathering of silicate minerals and their reaction with atmospheric $\mathrm{CO}_{2}$. This method works with using either natural alkaline earth metal oxides (mainly $\mathrm{CaO}$ and $\mathrm{MgO}$ ) bearing minerals, for example, various ultramafic mine waste [9-11], or industrial waste such as coal or oil shale ash (OSA), steel slag and other waste products [7, 12-14]. Sequestration can be carried out by carbonation either in-situ at suitable geological sites and waste heaps or ex-situ at plants or $\mathrm{CO}_{2}$ point sources before the final deposition of the material. Various types of industrial waste with a high content of chemically active alkaline metal oxides, such as $\mathrm{CaO}$ and $\mathrm{MgO}$, can provide an effective and readily available opportunity for $\mathrm{CO}_{2}$ sequestration. These waste streams originate from big industrial $\mathrm{CO}_{2}$ emitters and the proximity of the latter to the above geological sites favours the possible exploitation of the streams for $\mathrm{CO}_{2}$ sequestration. Although the volume of such waste is comparatively small and it can only mitigate part of the emitted carbon dioxide, it could constitute an additional and easily accessible reactive resource for $\mathrm{CO}_{2}$ sequestration. For example, it has been shown that coal ash with a $\mathrm{CaO}$ content of only about $4.1 \mathrm{wt} \%$ has a high potential for binding $\mathrm{CO}_{2}$, sequestering up to $26 \mathrm{~kg}$ per tonne of ash [15].

The Estonian energy sector relies on the oil shale industry. This has enabled Estonia to enjoy energy independence ever since the 1960s, however, at the cost of clean environment. The oil shale industry is by far the largest national producer of solid waste and emitter of greenhouse gases, being responsible for over $70 \%$ of the country's $\mathrm{CO}_{2}$ emissions [16]. According to EU statistics, in 2018 Estonia was, with 18.6 metric tonnes per capita, the largest producer of 
$\mathrm{CO}_{2}$ in Europe [17]. In 2019, however, power production and, consequently, the $\mathrm{CO}_{2}$ emissions from the oil shale industry nearly halved [18] as a direct consequence of an increase in carbon dioxide emission allowance prices under the European Union Emission Trading Scheme (EU ETS), which makes fossil fuels uncompetitive on the open Nord Pool energy market in which Estonia participates [19].

The fossil fuel used in Estonian power plants and shale oil retorts is kukersite oil shale, a kerogenous solid fuel with a high mineral content and a low calorific value, $8-12 \mathrm{MJ} / \mathrm{kg}$ [20]. In the recent years around $15 \mathrm{Mt}$ of calcareous OS has been mined in Estonia and about 6-8 Mt of ash has been produced annually $[18,21,22]$. High-temperature $\left(>1200-1400^{\circ} \mathrm{C}\right)$ pulverized combustion (PC) technology was the main method for processing OS up until 2018, but has been replaced by circulated fluidized bed combustion (CFBC) technology operating at $700-800{ }^{\circ} \mathrm{C}$, which had been gradually implemented since 2004. PC boilers emit up to one tonne of $\mathrm{CO}_{2}$ per tonne of fuel [23], but CFBC emits up to $13 \%$ less [24], largely due to the lower extent of carbonate decomposition in low-temperature combustion (decomposition extent 0.97 in $\mathrm{PC}$ and 0.60 in $\mathrm{CFBC}$ ) [25].

There are no proven natural geological structures with required properties for carbon capture and long-term storage in Estonia and, requiring large capital investments, the long-range transport of $\mathrm{CO}_{2}$ to suitable storage sites hundreds or thousands of kilometers away is currently economically unfeasible. In addition, this would increase the environmental impact of CCS [25-27]. However, the ash produced by combustion of calcareous Estonian oil shale may contain up to $27 \mathrm{wt} \%$ of free lime $\left(\mathrm{CaO}_{\text {free }}\right)$ [28], constituting a potential $\mathrm{CO}_{2}$ sink. Although the mineral matter in OS contains $50-70 \mathrm{wt} \%$ of carbonate minerals on average, most of the free $\mathrm{CaO}$ originating from the decomposition of carbonate minerals calcite and dolomite further reacts with $\mathrm{Ca}$ - and $\mathrm{Ca} / \mathrm{Mg}$-silicate, $\mathrm{Ca}$-sulphate and other non-carbonate minerals. Thus, not all of the $\mathrm{CaO}$ from the carbonate mineral decomposition is available for $\mathrm{CO}_{2}$ capture, whereas $\mathrm{MgO}$ that forms after decomposition of dolomite is primarily found as periclase and $\mathrm{Ca} / \mathrm{Mg}$-silicates such as merwinite and akermanite [28, 29]. The theoretical $\mathrm{CO}_{2}$ capture capacity of PC oil shale ash is $350-500 \mathrm{~kg}$ of $\mathrm{CO}_{2}$ per tonne of ash, 30-50\% of which is based on free lime [30]. Previous laboratory carbonation experiments have estimated that only about $4-5 \%$ of total $\mathrm{CO}_{2}$ or about $20 \%$ of carbonate $\mathrm{CO}_{2}$ emitted during oil shale combustion is bound back by the carbonation of OSA sediments [31]. However, a much higher potential of up to $11 \%$ of total emissions or $209 \mathrm{~kg}$ of $\mathrm{CO}_{2}$ per one tonne of ash (including neutralizing transport water) has been achieved in subsequent laboratory-scale experiments [32]. In contrast to laboratory-scale experiments that often reach an equilibrium state, the carbonation reactions in natural conditions within ash deposits are not completed due to the continuous deposition of new material, environmental constraints and inhibited transport (availability) of $\mathrm{CO}_{2}$ through solidified ash $[21,28]$. 
The ash forming at power plants and shale oil retorts is transported mixed with water (water/solid matter ratio ca 20:1) to waste disposal ponds next to the processing plants where the slurry solidifies [33]. During the 70 years of operation, more than 300 million tonnes of ash has been deposited in plateau-like waste depositories up to $45 \mathrm{~m}$ high, covering more than $20 \mathrm{~km}^{2}$ [21]. In field conditions it has been suggested that ca $5-6 \%$ of $\mathrm{CO}_{2}$ emitted during OS combustion is bound back from the atmosphere in ash waste deposits and sediment ponds [22]. However, the extent of carbonation reactions taking place within the ash deposits themselves has not been studied as yet. Recent assessments of the phase composition of ash deposit sediments show a major increase in the semicrystalline calcium silicate hydrate phase (C-S-H-type phases) over time in ash deposits that are likely to negatively impact the previously estimated $\mathrm{CO}_{2}$ sequestration ability of the material [29].

This contribution aims to firstly elucidate the long-term $\mathrm{CO}_{2}$ binding capacity of oil shale ash sediment under natural conditions by using drill core material from ash waste deposits spanning nearly 50 years of sedimentation and mineral-chemical transformation. Secondly, we explore the extent to which the material stored in ash depositories can be used for further $\mathrm{CO}_{2}$ sequestration by in-situ accelerated carbonation.

\section{Materials and methods}

The material for the study was sampled from three drill cores penetrating the ash deposits in Northeast Estonia (Fig. 1), drill core 2 at Eesti Power Plant (EPP) and drill cores 5 and 6 at Balti Power Plant (BPP). The sampled material represents bulk ash sediments that are thoroughly mixed during the dam building process. These two power plants (PPs) are the largest oil shale operations, commissioned in 1969 and 1959, respectively. The ash depository at EPP also receives ash from the new Auvere PP, commissioned in 2016, as well as solid heat carrier oil retorts ever since the 1980s, including the newest Enefit-280 shale oil plant that has been in operation since 2012 [28, 34]. Both PPs used PC technology up to the mid-2000s, but installed lower-temperature CFBC boilers in 2004. In addition, ash from CFBC boilers has been deposited at both sites, influencing the composition of the upper section of ash deposits. These deposits have been in continuous use ever since the commissioning of their respective PPs and the composition of fuel (calcareous oil shale) has not changed over time.

The thickness of ash waste sediments at the drilling site of EPP ash deposit was $37.5 \mathrm{~m}$ and the groundwater level in the drill hole at the time of drilling was measured at 6.6 meters below the surface. Drill cores 5 and 6 in the ash depository at BPP reached $32 \mathrm{~m}$ and $26 \mathrm{~m}$ in depth, respectively, while the groundwater level was measured at 16-18 $\mathrm{m}$ during drilling in drill hole no 5 and at 6-8 $\mathrm{m}$ in drill hole no 6 (Fig. 1). 
The mineral and chemical composition of the studied ash sediment samples from drill core 2 at EPP ash depository has previously been reported by Leben et al. [29]. In the current study, the mineral composition of BPP ash sediments was analysed in 70 samples obtained from the two drill cores with a sampling interval of $0.5-1.5$ meters to represent the whole section. The X-ray diffraction (XRD) analysis of ash waste materials was carried out on powdered unoriented preparations by using a Bruker D8 Advance diffractometer. Rietveld analysis of XRD patterns was carried out using the Topas code. The C-S-H-type phase was modelled via a tobermorite-like structure that provides a rough estimate of this gel-like semicrystalline compound. The relative error of quantification was better than $10 \mathrm{wt} \%$ for major phases (content $>5 \mathrm{wt} \%$ ) and better than $20 \mathrm{wt} \%$ for minor phases (content $<5 \mathrm{wt} \%$ ). For $\mathrm{C}-\mathrm{S}-\mathrm{H}$ the estimated relative error was in the same range with minor phases, i.e. up to $20 \%$. Leben et al. [29] used pressed pellets to determine the chemical composition of ash sediments by X-ray fluorescence spectroscopy (XRF) using a Rigaku Primus II spectrometer.

(a)

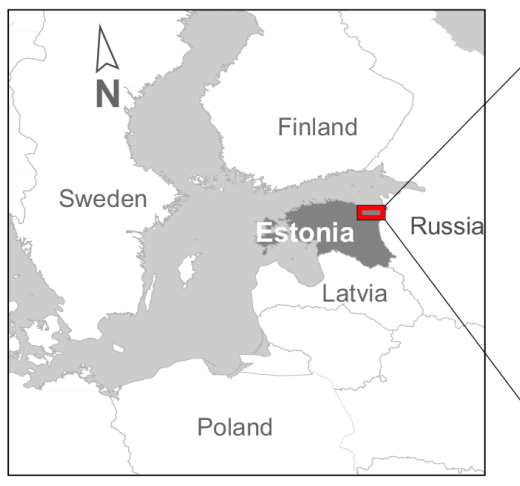

(c)

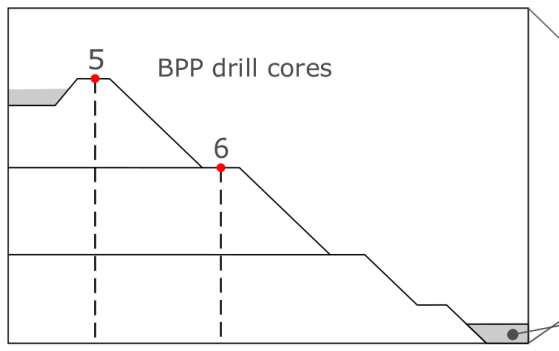

(b)

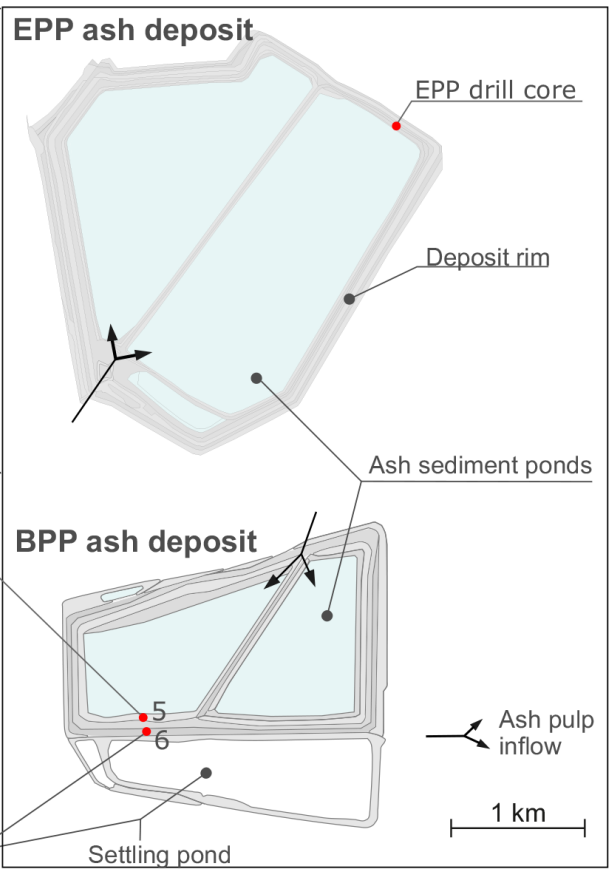

Fig. 1. The location and overview of ash waste deposits and drill cores: (a) the location of oil shale power plants and studied ash depositories; (b) the location of studied drill cores in depositories; (c) the schematic cross-section of BPP rim and the location of drill cores 5 and 6 . 


\section{Results and discussion}

\subsection{The composition and transformation of Ca-rich ash in deposits}

The chemical composition of the studied EPP oil shale ash waste sediments has been reported by Leben et al. [29]. The sediments overall chemical composition is characterized by average $\mathrm{Ca}$ content, expressed as $\mathrm{CaO}$ at $40.9 \mathrm{wt} \%$ (variation 25.5-50.8 wt \%); $\mathrm{SiO}_{2}$ varies between 12.5 and $27.6 \mathrm{wt} \%$, $\mathrm{Al}_{2} \mathrm{O}_{3}$ from 4.6 to $11.9 \mathrm{wt} \%$ and $\mathrm{SO}_{3}$ between 2.6 and $9.2 \mathrm{wt} \%$. The content of other elements remains below $5 \mathrm{wt} \%$.

The mineral composition of major phases in ash sediments from the studied drill cores is shown in Figure 2 and Supplementary Table. The mineral phase composition of ash sediments is dominated by the alteration of secondary and terrigenous minerals. The secondary minerals are represented by phases formed during high-temperature combustion and subsequent hydration, carbonation and diagenesis on deposition. Making up an average of 6.6, 25.2 and 18.6 wt\% in the EPP ash depository drill core and BPP drill cores 5 and 6, respectively, carbonates (calcite and vaterite) are the main compounds of said minerals. The combined average content of secondary $\mathrm{Ca}$ hydrate-sulphate-silicate phases portlandite, ettringite and thaumasite for the three drill cores is 5.1, 5.0 and $4.1 \mathrm{wt} \%$, respectively, but it can vary considerably. The semicrystalline phase composition is characterized by the C-(A)-S-H-type phase with a trend of increasing content towards the bottom of the deposit, with estimated values ranging from ca $20 \mathrm{wt} \%$ to more than $60 \mathrm{wt} \%$ in the EPP depository and ca $40 \mathrm{wt} \%$ in BPP ash waste deposit drill core 6 . However, in BPP drill core 5 the C-(A)-S-H phase shows a U-shaped trend from top to bottom, starting from $30-40 \mathrm{wt} \%$ and, after dropping to $5-10 \mathrm{wt} \%$ in the middle part at a depth of $10-17 \mathrm{~m}$, increases again to $30-40 \mathrm{wt} \%$ in the lower half of the drill core (Fig. 2). The content of primary silicate phases ranges from a few per cent to over $50 \mathrm{wt} \%$, being mainly characterized by such silicate minerals as quartz and $\mathrm{K}$-feldspar, as well as minor amounts of micas.

The composition of ash sediment in waste depositories is dictated, first of all, by the composition of ash forming in boilers and its sequential hydration reactions during and after the deposition [21]. The ash from the two power plants is rich in reactive secondary Ca-phases, such as lime $\left(\mathrm{CaO}_{\text {free }}\right)$ and anhydrite, as well as secondary $\mathrm{Ca} / \mathrm{Mg}$-silicates. These phases form during the thermal decomposition of carbonate minerals (calcite and dolomite) present in raw $\mathrm{OS}$ and the reactions during combustion between $\mathrm{CaO}_{\text {free }}$ (and free $\mathrm{MgO}$ ) and silicates as well as flue gases, mainly $\mathrm{SO}_{2}$ (e.g., Bityukova et al. [35]). Lime slaking (reaction 1) and the formation of portlandite starts already during the transportation and deposition of ash:

$$
\mathrm{CaO}+\mathrm{H}_{2} \mathrm{O} \rightarrow \mathrm{Ca}(\mathrm{OH})_{2}
$$




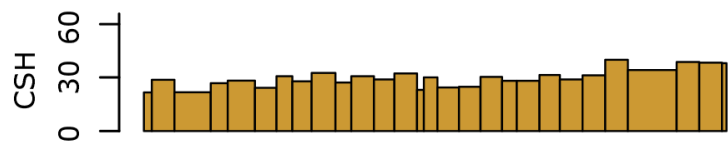

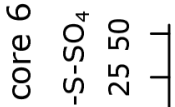

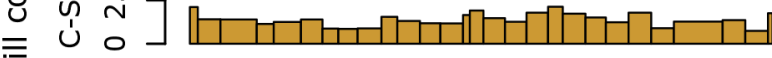

든
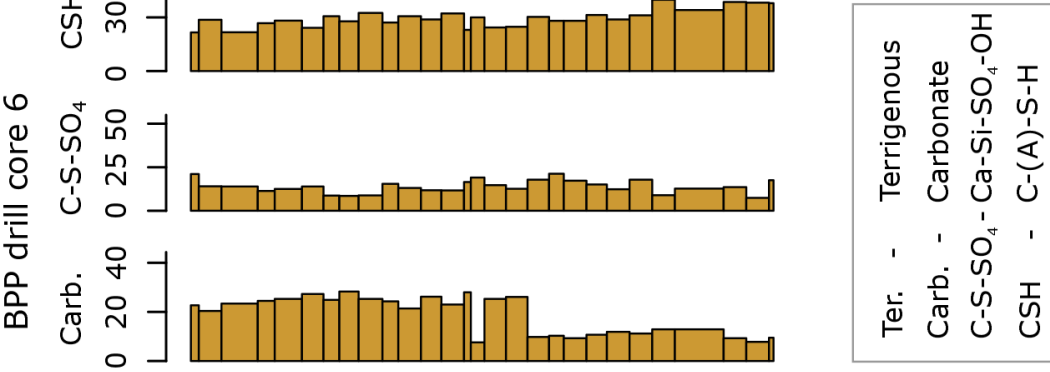

蛋

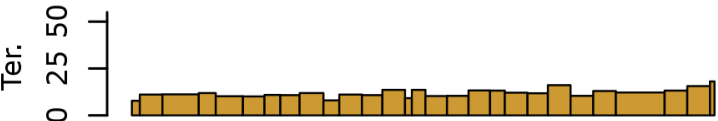

$\left.\begin{array}{l}0 \\ 0 \\ \text { In } \\ 0 \\ 0\end{array}\right]$

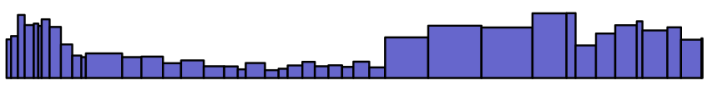

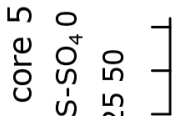

三 نे

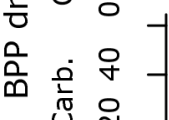

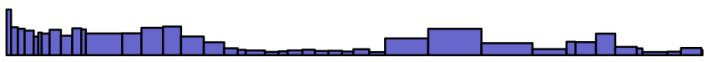

$1,0^{2}$

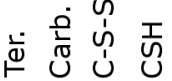
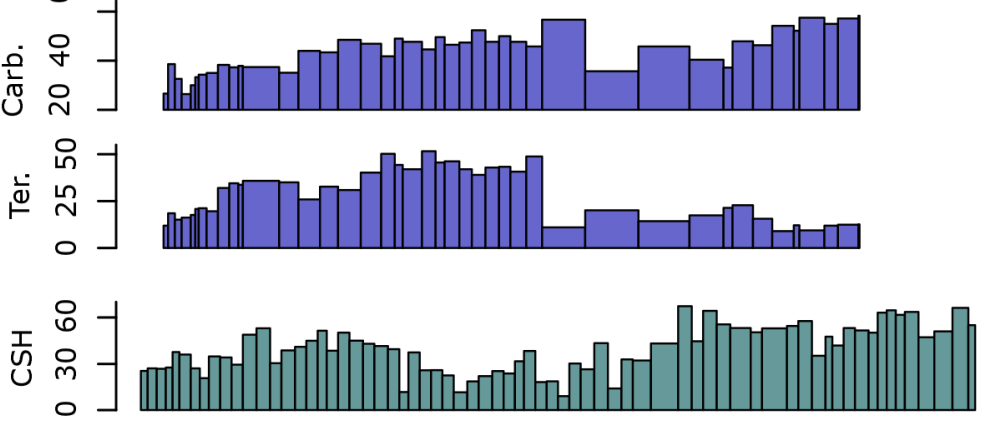

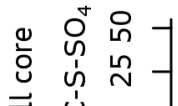

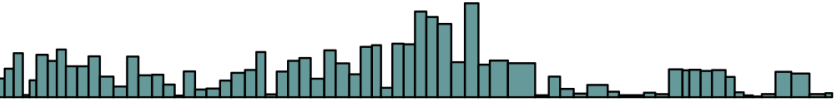

品

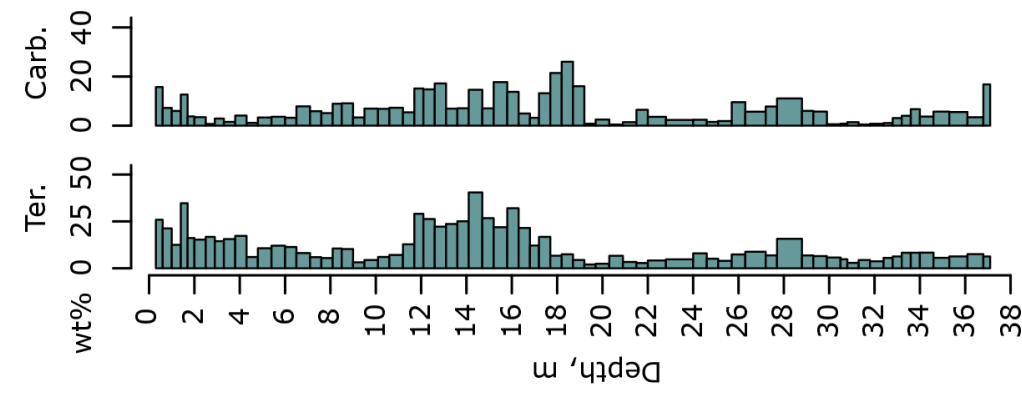

ш ‘чวdә0

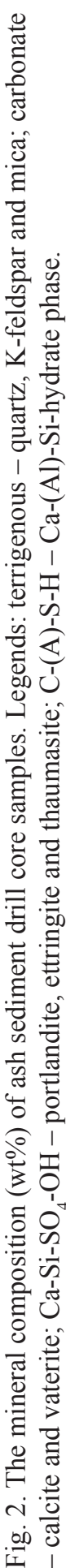


This is followed by the dissolution of anhydrite and subsequent reactions involving dissolved $\mathrm{Ca}$, sulphate and $\mathrm{Al}$, producing ettringite type phases (2):

$3 \mathrm{Ca}(\mathrm{OH})_{2}+2 \mathrm{Al}(\mathrm{OH})_{3}+3 \mathrm{CaSO}_{4}+26 \mathrm{H}_{2} \mathrm{O} \rightarrow \mathrm{Ca}_{6} \mathrm{Al}_{2}\left(\mathrm{SO}_{4}\right)_{3}(\mathrm{OH})_{12} \cdot 26 \mathrm{H}_{2} \mathrm{O}$.

Earlier studies (e.g., Liira et al. [36]) have shown that ettringite forms over a period of about two weeks, followed by the formation of the hydrocalumite type phase $\left[\mathrm{Ca}_{2} \mathrm{Al}(\mathrm{OH})_{7} \cdot 3 \mathrm{H}_{2} \mathrm{O}\right]$ and/or gypsum $\left(\mathrm{CaSO}_{4} \cdot 2 \mathrm{H}_{2} \mathrm{O}\right)[21,36]$. Most recently, Leben et al. [29] have suggested that the long-term transformation of Ca-rich ash sediments within ash depositories is governed by alkali-activated recrystallization, producing a semicrystalline C-(A)-S-H type phase along with $\mathrm{Ca}-\mathrm{Si}-\mathrm{CO}_{3}$-sulphate mineral thaumasite, the latter probably forming at the expense of ettringite. The C-S-H type phase forms by the recrystallization of either Ca-silicate minerals (e.g., belite $\mathrm{C}_{2} \mathrm{~S}$ ) and/or aluminosilicates and glassy phases present in ash. The hydration of secondary Ca-silicate minerals can produce additional portlandite [37].

\section{2. $\mathrm{CO}_{2}$ binding processes and rates in Ca-rich ash deposits}

In terms of composition, Ca-rich oil shale ash sediment is comparable to other natural alkaline metal-bearing minerals widely available in igneous and metamorphic rocks, but the latter also require energy-intensive processing in order to bind carbon dioxide $[6,7,38]$. However, there are examples of using natural geological processes (e.g., Magbitang and Lamorena [39]), as well as ultramafic mine tailings $[9,40]$, as carbon sinks, which do not require significant external energy input. Though, the industrial-scale applicability of these processes has yet to be determined. A faster and less energy dependent substitute for natural silicates for carbon mineralization would be metal oxides $(\mathrm{CaO}, \mathrm{MgO})$ bearing industrial waste that can often be found near the point sources of $\mathrm{CO}_{2}$, e.g. Ca-rich oil shale ash deposits in Estonia.

Carbon dioxide sequestration in OSA deposits relies mostly on the carbonation of portlandite (3) which mainly forms by the slaking of lime and the hydration of $\mathrm{Ca}$-silicate minerals present in raw ash:

$$
\mathrm{Ca}(\mathrm{OH})_{2}+\mathrm{CO}_{2} \rightarrow \mathrm{CaCO}_{3}+\mathrm{H}_{2} \mathrm{O} .
$$

Additional $\mathrm{CO}_{2}$ binding capacity in hydrated OSA can be provided by the decomposition and carbonation of ettringite (4) and secondary Ca-silicate phases (5) producing Ca-sulphate, Al-hydroxide and/or silica, as well as calcium carbonate phases [41]:

$$
\begin{aligned}
& \mathrm{Ca}_{6} \mathrm{Al}_{2}\left(\mathrm{SO}_{4}\right)_{3}(\mathrm{OH})_{12} \cdot 26 \mathrm{H}_{2} \mathrm{O}+3 \mathrm{CO}_{2} \rightarrow 3 \mathrm{CaCO}_{3}+2 \mathrm{Al}(\mathrm{OH})_{3} \\
& +3 \mathrm{CaSO}_{4} \cdot 0.5 \mathrm{H}_{2} \mathrm{O}+27.5 \mathrm{H}_{2} \mathrm{O}
\end{aligned}
$$




$$
\mathrm{Ca}_{2} \mathrm{SiO}_{4}+2 \mathrm{CO}_{2} \rightarrow 2 \mathrm{CaCO}_{3}+\mathrm{SiO}_{2} .
$$

The presence of thaumasite $\left(\mathrm{Ca}_{3} \mathrm{Si}(\mathrm{OH})_{6}\left(\mathrm{CO}_{3}\right)\left(\mathrm{SO}_{4}\right) \cdot 12 \mathrm{H}_{2} \mathrm{O}\right)$ in oil shale ash sediment (up to $30 \mathrm{wt} \%$ ) also indicates that at least some of the $\mathrm{CO}_{2}$ is bound by this mineral. This has previously not been taken into account in estimating the $\mathrm{CO}_{2}$ sequestration capacity in OSA waste. Thaumasite can form at the expense of ettringite in the presence of dissolved silica and dissolved inorganic carbon, or alternatively as a result of the carbonation of the C-S-H gel-like phase and the consumption of portlandite [42, 43], providing an additional $\mathrm{CO}_{2}$ sink in ash sediments.

Under laboratory conditions the carbonation of portlandite, the main $\mathrm{CO}_{2}$ binding phase in OSA, takes place over several weeks or months [44]. Geochemical modelling and laboratory-scale studies of oil shale ash carbonation $[30,31,45-49]$ show that $\mathrm{CO}_{2}$ sequestration in this material is viable and that $\mathrm{PC}$ oil shale ash has a theoretical $\mathrm{CO}_{2}$ capture capacity of $350-500 \mathrm{~kg}$ of $\mathrm{CO}_{2}$ per one tonne of ash, with $30-50 \%$ of this potential being based on free lime. However, in agreement with findings of Mõtlep et al. [21] and Leben et al. [29], our results show that abundant portlandite is still found at deep levels throughout the plateau sediment succession. This implies retarded carbonation, which is most possibly the result of inhibited transport of $\mathrm{CO}_{2}$ dissolved in the ash transport water and rainwater infiltrating into the ash deposit.

Based on the mineral composition of ash and ash sediments it is possible to estimate their $\mathrm{CO}_{2}$ binding potential. Firstly, it is necessary to account for the residual carbonate content in fresh ash. In older PC boilers, almost all carbonates are thermally decomposed (decomposition extent as high as $98 \%$ ), but the carbonate decomposition extent in lower-temperature CFBC boilers can vary between 47 and $96 \%$ for different ash fractions [50]. The average residual primary calcite content in PC ash is estimated at $5.16 \%$ of crystalline phases (Table 1), calculated using the calcite content and the proportion of different ash fractions in fresh ash, using data obtained by Bityukova et al. [35] and Konist et al. [51]. Given that CFBC ash with a lower decarbonation extent has been deposited in ash plateaus only during the last decade and that PC ash prevails in ash deposits, this calculated average calcite content estimate can be used to describe the primary carbonate share in average ash stream.

In raw ash, the content of amorphous glassy material typically not detected in X-ray diffraction analysis is estimated at $29 \mathrm{wt} \%$ on average [21]. This means that the content of primary carbonate is ca $30 \mathrm{wt} \%$ lower, making up $3.6 \mathrm{wt} \%$ of bulk material on average, including crystalline and amorphous phases. Similarly, the assessment of carbonation extent with X-ray diffraction data requires taking the share of amorphous C-(A)-S-H-type phases into account when calculating general mass balance. The content of secondary Ca-carbonate minerals (calcite and vaterite) formed by $\mathrm{CO}_{2}$ uptake in ash sediments varies largely, between 0 and $35 \%$. The respective amount of 
Table. Average primary calcite content in the crystalline fraction of different PC ash fractions $[35,51]$

\begin{tabular}{|l|c|c|c|}
\hline Ash fraction & $\begin{array}{c}\text { Calcite, } \\
\text { wt } \%\end{array}$ & $\begin{array}{c}\text { Proportion of ash, } \\
\%\end{array}$ & $\begin{array}{c}\text { Calcite in total ash prior } \\
\text { to storage, wt } \%\end{array}$ \\
\hline Furnace & 6.4 & 42.1 & 2.69 \\
Super heater & 3.3 & 3.7 & 0.12 \\
Economizer & 4.4 & 4.7 & 0.21 \\
Cyclone separator & 4.2 & 14.5 & 0.61 \\
1st el. precipitator & 4.3 & 28.3 & 1.22 \\
2nd el. precipitator & 4.7 & 5.6 & 0.26 \\
3rd el. precipitator & 4.2 & 1.1 & 0.05 \\
Total & - & - & 5.16 \\
\hline
\end{tabular}

Abbreviation: el. - electric.

$\mathrm{CO}_{2}$ bound to ash sediment ranges from 0 to $153 \mathrm{~kg}$ of $\mathrm{CO}_{2}$ per tonne of the sediment. There is a high variability between the analysed drill cores in the average content of bound $\mathrm{CO}_{2}$, this being 1.6, 8.9 and $6.6 \mathrm{wt} \%$ for the EPP drill core and BPP drill cores 5 and 6, respectively. In addition to Ca-carbonates, the Ca-silicate-sulphate mineral thaumasite also binds a fraction of carbon dioxide. The $\mathrm{CO}_{2}$ in thaumasite can be of atmospheric origin or originate from the dissolution of carbonates $[52,53]$. Calcite and vaterite are stable phases in the $\mathrm{pH}$ range of $12-13$, which is characteristic of the water in contact with OSA [28], and also over a wide range of dissolved sulphate and/or silica activities. This suggests that most of the $\mathrm{CO}_{2}$ likely originates from the atmospheric $\mathrm{CO}_{2}$, rather than from the dissolution of carbon bearing phases. Carbon dioxide bound to thaumasite ranges from 0 to $22.8 \mathrm{~kg}$ of $\mathrm{CO}_{2}$ per tonne of ash sediment with an average of $3 \mathrm{~kg} / \mathrm{t}$ (Fig. 3, Supplementary Table).

These results show that Ca-rich ash sediments deposited over a long period of time display highly variable $\mathrm{CO}_{2}$ binding rates which remain far below the previously reported values. The average $\mathrm{CO}_{2}$ sequestration capacity in carbonates is only $4.8 \mathrm{wt} \%$ or $48 \mathrm{~kg}$ per tonne of ash sediment when considering the composition of all three drill core sections. As the water-binding capacity of dry ash is $0.15 \mathrm{~m}^{3}$ per tonne on average, being mainly caused by the formation of portlandite, gypsum, ettringite and various other hydrates [36], then ca $41 \mathrm{~kg}$ of $\mathrm{CO}_{2}$ is bound per tonne in ash deposits on dry ash basis. Adding the $\mathrm{CO}_{2}$ bound in thaumasite, the total average amount of bound $\mathrm{CO}_{2}$ rises to $4.3 \mathrm{wt} \%$ or $43 \mathrm{~kg}$ per tonne of dry ash $(51 \mathrm{~kg} /$ tonne of ash sediment). This suggests that thaumasite accounts for about $6 \%$ of the total bound $\mathrm{CO}_{2}$ 


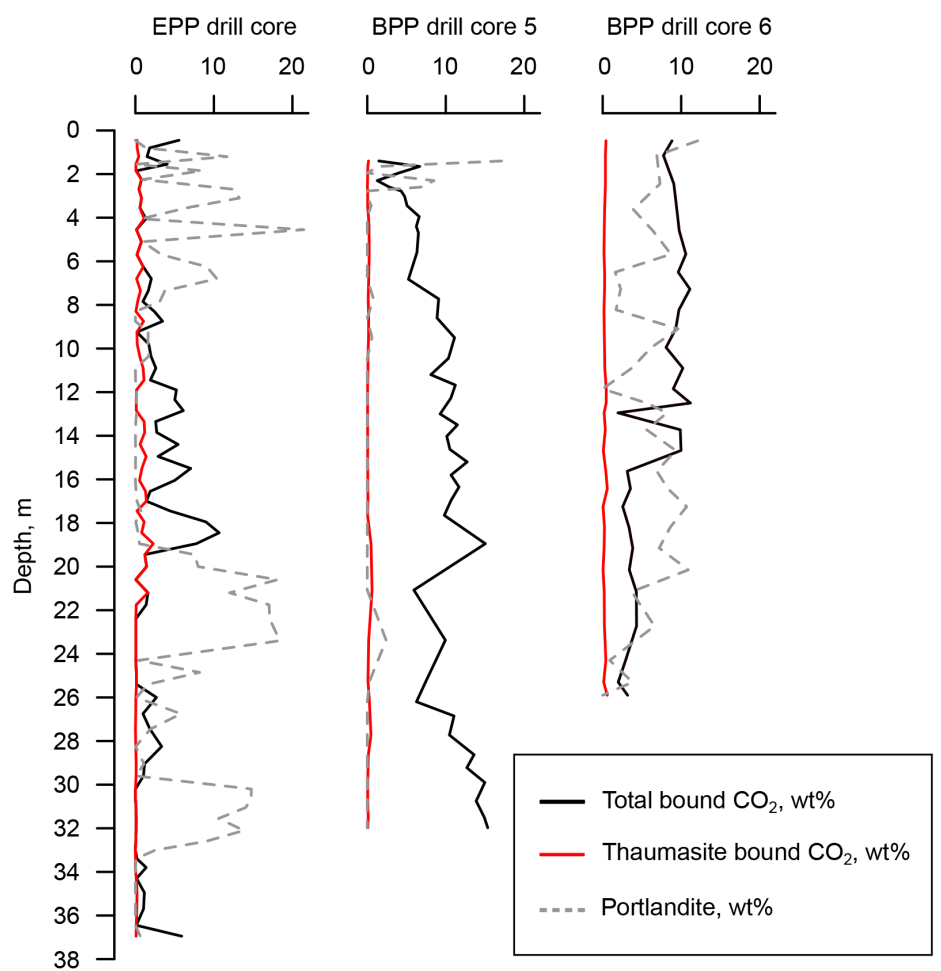

Fig. 3. $\mathrm{CO}_{2}$ binding rate in ash sediment samples.

on average. Furthermore, in several intervals, particularly in the drill core succession of EPP ash depository, the estimated content of $\mathrm{CO}_{2}$ bound in ash sediment was close to or below the level of $\mathrm{CO}_{2}$ assumed to be included in the average estimated primary calcite composition, which indicates a zero net uptake of $\mathrm{CO}_{2}$ by ash sediments.

The high variation in $\mathrm{CO}_{2}$ bound in the mineral form in ash deposits is firstly caused by the compositional heterogeneity of ash sediments and secondly by the inhibited $\mathrm{CO}_{2}$ transport to the sediment pile. The long-term variability in $\mathrm{CO}_{2}$ uptake is partially caused by the seasonal and historical changes in the production capacity of the plants. Namely, after the fall of the former Soviet Union, there was a large drop in production, from 15 million to 7-9 million tonnes per year. In 2019 it fell further to ca 4-5 million tonnes per year, due to the significantly reduced oil shale firing under current carbon dioxide trade policies. The ash deposits are sequentially built up, layer by layer, by the deposition of the ash-water slurry in the temporary ponds on the top of plateau-like ash deposits $[28,33]$. The thickness of a typical layer varies from 0.2 to $>1 \mathrm{~m}$ [33] with earlier studies having revealed a highly variable layered structure of ash plateaus [54]. The layers showing lower $\mathrm{CO}_{2}$ binding rates can likely be associated with higher ash production periods, 
more rapid burial and therefore a shorter and more inhibited contact with $\mathrm{CO}_{2}$. For example, this is true for the layers in the lower section of the EPP drill core at depths between 20 and 25 meters (Fig. 3). Also, because of grain size separation in the settling of the ash-water slurry along about a $3000 \mathrm{~m}$ long flow path, the coarse-grained fractions of bottom ash are deposited at the inlet of the slurry, with progressively finer particles mainly represented by the fly ash fractions settling further along the flow path. This causes the lateral variation in ash composition [33]. In addition, the position of the slurry inlet and the flow path of braided streams are changed at each filling step, causing further grain size and compositional spatial variation. Arro et al. [54] have shown that coarse-grained bottom ash fractions form loose and porous ash sediment beds, while fine-grained ash forms nearly impermeable and hard layers with transverse filtration modules as low as $0.15 \cdot 10^{-9} \mathrm{~m} / \mathrm{s}$. It is evident that such dense layers significantly reduce both water and $\mathrm{CO}_{2}$ transport from the top of the plateau down to its deeper parts. According to Konist et al. [22] the binding of $\mathrm{CO}_{2}$ mostly takes place during ash-water transport and within the surface (layers) of deposits, but it stops when the contact with ambient air is lost. However, it is possible that $\mathrm{CO}_{2}$ transport following ash deposition occurs more readily through $30-40 \mathrm{~m}$ high steep (ca 30 degrees) walls of the depositories, preferentially via coarser-grained ash beds composed of hydrated bottom ash particles (Fig. 4). Furthermore, the material at the sides of the plateaus is thoroughly mixed during the dam building process, which further facilitates $\mathrm{CO}_{2}$ uptake. As a result, following the initial phase during deposition, carbonation mainly occurs at the sides of ash deposits and the full potential of $\mathrm{CO}_{2}$ sequestration in hydrated ash deposits is not achieved. This

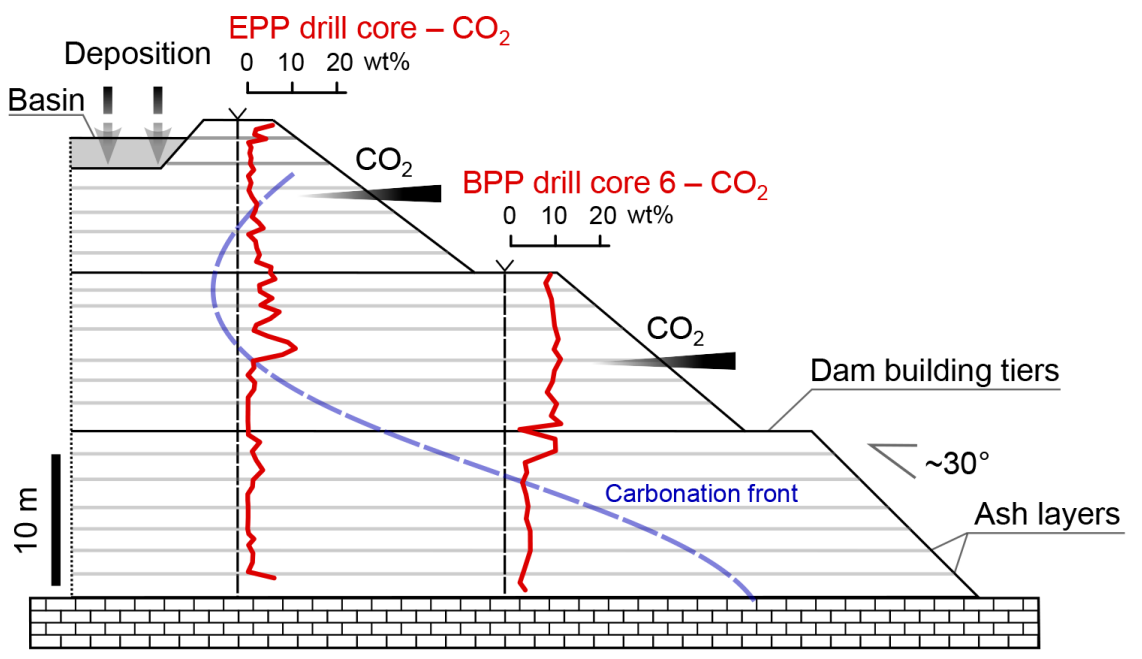

Fig. 4. A conceptual (not-to-scale) scheme of $\mathrm{CO}_{2}$ uptake in the ash deposits. The carbonation line is drawn based on the presence of portlandite. 
is well evident from the survival of Ca-hydroxide (portlandite) throughout the ash sediment successions (Fig. 3). Although some portlandite can also be of secondary origin, formed during alkali-activation and the formation of $\mathrm{C}-\mathrm{S}$-H-type phases from Ca-silicates, its presence nevertheless hints at limited $\mathrm{CO}_{2}$ transport and carbonation processes inside the ash plateau sediments. In addition, the carbonation of portlandite at the edges of the ash deposits causes a significant pore space closure, further inhibiting this process inside the ash piles.

\section{3. $\mathrm{CO}_{2}$ binding potential of Ca-rich ash deposits}

Our results show that under natural conditions the full $\mathrm{CO}_{2}$ binding capacity of the ash sediments has not been reached during the last 50 years. If the calculated binding rate ( $48 \mathrm{~kg} /$ tonne of ash sediment) is applied to the recent annual ash production of 7.2 Mt, with $\mathrm{CO}_{2}$ emissions being at $11.3 \mathrm{Mt}$ [18], we find that on average only about $3.06 \%$ of $\mathrm{CO}_{2}$ is bound by OSA waste in the long term. When taking thaumasite into consideration and calculating the amount of $\mathrm{CO}_{2}$ based on dry ash binding capacity $(43 \mathrm{~kg} / \mathrm{t})$, on average $2.74 \%$ of emissions is bound to ash sediment annually. This is well below the previously assessed lower end values of $4 \% \mathrm{CO}_{2}$ bound to ash depositories [31]. Given that ash production rates and the respective $\mathrm{CO}_{2}$ emissions were more than twice as high in the mid-1980s and that the studied drill cores were situated at the edges of the ash plateaus with a more advanced carbonation rate, we suggest that the overall binding capacity has most probably been overestimated by as much as an order of magnitude.

Assuming that the lower half of the deepest dill core in the ash depository at EPP represents the composition of ash sediments inside the ash pile away from the walls, less than $1 \%$ of $\mathrm{CO}_{2}$ emissions has been bound by said sediments so far. Nevertheless, Uibu and Kuusik [30] have demonstrated the high $\mathrm{CO}_{2}$ sequestration capacity of OSA which is potentially achievable by the in-situ carbonation of ash sediment deposits. For instance, this can be achieved by constructing a network of drill holes through ash deposits, connected to the flue gases emitted by the nearby power plants, forcing accelerated in-situ carbonation. In addition to the carbonation of the available portlandite, the in-situ carbonation of ash deposits will lead to an extensive $\mathrm{Ca}$-carbonate formation at the expense of all Ca-containing phases, including ettringite, thaumasite and the C-S-H gel. While portlandite and ettringite are prone to full carbonation already at atmospheric $\mathrm{CO}_{2}$ partial pressures, the level of C-S-H carbonation is dependent on the concentration of $\mathrm{CO}_{2}[41,55]$. It has been shown that $\mathrm{C}-\mathrm{S}-\mathrm{H}$ with an initial $\mathrm{Ca} / \mathrm{Si}$ ratio of about 1.2 can become almost entirely carbonated in laboratory under exposed conditions in seven days to form ca $80 \mathrm{wt} \%$ of calcite and $15 \mathrm{wt} \%$ of silica gel [56]. In addition, Wu and Ye [57] have shown that nearly all C-S-H phases can be fully decomposed to $\mathrm{CaCO}_{3}$ and silica gel by accelerated carbonation at a $\mathrm{CO}_{2}$ partial pressure 
of $0.03 \mathrm{~atm}$ after three days, while phases with a higher $\mathrm{Ca} / \mathrm{Si}$ ratio are more resistant to carbonation. According to Leben et al. [29] the $\mathrm{Ca} / \mathrm{Si}$ ratio of the $\mathrm{C}-\mathrm{S}-\mathrm{H}-\mathrm{like}$ phase in ash sediments ranges from 1.5 to 2 and the phase is likely more resistant to carbonation.

The average contents of portlandite, ettringite and the C-S-H type phase in ash sediment samples are 5, 4.9 and $31.8 \mathrm{wt} \%$, respectively. The full carbonation of portlandite, ettringite and $80 \%$ calcite formation from the $\mathrm{C}-\mathrm{S}-\mathrm{H}$ phase would lead to an increase in the average $\mathrm{CO}_{2}$ content of ash sediment by $3,0.8$ and $11.2 \mathrm{wt} \%$, respectively. This would increase the sediment's potential $\mathrm{CO}_{2}$ binding capacity by $150 \mathrm{~kg} / \mathrm{t}$, resulting in a total of ca $200 \mathrm{~kg} / \mathrm{t}$. In addition, it is possible that at increased $\mathrm{CO}_{2}$ partial pressures in the flue gases and by using captured $\mathrm{CO}_{2}$ stream, other $\mathrm{Ca}$ and $\mathrm{Mg}$ phases such as thaumasite and minor phases such as $\mathrm{Ca}$ - and $\mathrm{Ca} / \mathrm{Mg}$-silicates, Ca-aluminates, periclase $(\mathrm{MgO})$ and Mg-hydroxide would also contribute to carbonation, further enhancing the $\mathrm{CO}_{2}$ binding capacity of oil shale ash.

\section{Conclusions}

The long-term $\mathrm{CO}_{2}$ sequestration in Ca-rich oil shale ash sediments under natural conditions was studied by analysing the drill core material from $\mathrm{Ca}$-rich ash waste deposits in Estonia, which contain more than 300 million tonnes of ash. The material shows high compositional variability, with an average, mainly carbonate-bound $\mathrm{CO}_{2}$ content in ash sediments varying between 1.6 and $8.9 \mathrm{wt} \%$ in different drill cores. On average, the $\mathrm{CO}_{2}$ binding rate of oil shale ash sediment deposited in waste depositories was found to be $51 \mathrm{~kg}$ per tonne, including the Ca-silicate thaumasite, which accounts for about $6 \%$ of the total bound carbon dioxide. This is ca 5 to 6 times less than the estimated binding capacity in laboratory-scale experiments. Under natural conditions, carbonation is significantly hindered by limited $\mathrm{CO}_{2}$ transport and only the outer perimeter of up to 40-45 m high ash deposits has likely been carbonated, leaving the internal part of the ash pile unreacted, as evidenced by the preservation of Ca-hydroxide in the deeper parts of the sections. The $\mathrm{CO}_{2}$ sequestration potential of ash sediments can be increased by in-situ carbonation, using flue gases from the nearby power plants. Assuming full carbonation of the major phases, i.e. portlandite, ettringite and C-S-H, the average $\mathrm{CO}_{2}$ binding capacity of ash can be increased by about $150 \mathrm{~kg} / \mathrm{t}$, resulting in a total estimation of ca $200 \mathrm{~kg} / \mathrm{t}$. At current production rates, however, the ash from CFBC boilers which replaced the former PC technology is deposited in lower rates. This will likely increase the $\mathrm{CO}_{2}$ binding rate in the surface layers of the deposited ash sediment due to the prolonged $\mathrm{CO}_{2}$ contact. 


\section{Acknowledgements}

This work was funded by the Estonian Research Council within the framework of the National Programme for Addressing Socio-Economic Challenges through R\&D (RITA) which is supported by the Estonian Government and the European Regional Development Fund. The studied ash sediment samples were provided by Eesti Energia AS. The authors would like to thank Jaan Aruväli for helping with laboratory analyses.

\section{REFERENCES}

1. Horowitz, C. A. Paris Agreement. Int. Leg. Mater, 2016, 55(4), 740-755.

2. European Commission. Communication from the Commission to the European Parliament, the European Council, the Council, the European Economic and Social Committee and the Committee of the Regions, 2019.

3. Aminu, M. D., Nabavi, S. A., Rochelle, C. A., Manovic, V. A review of developments in carbon dioxide storage. Appl. Energy, 2017, 208, 1389-1419.

4. Bui, M., Adjiman, C. S., Bardow, A., Anthony, E. J., Boston, A., Brown, S., Fennell, P. S., Fuss, S., Galindo, A., Hackett, L. A., Hallett, J. P., Herzog, H. J., Jackson, G., Kemper, J., Krevor, S., Maitland, G. C., Matuszewski, M., Metcalfe, I. S., Petit, C., Puxty, G., Reimer, J., Reiner, D. M., Rubin, E. S., Scott, S. A., Shah, N., Smit, B., Trusler, J. P. M., Webley, P., Wilcox, J., Dowell, N. M. Carbon capture and storage (CCS): the way forward. Energy Environ. Sci., 2018, 11(5), 1062-1176.

5. IPCC. Climate Change 2007: Mitigation of Climate Change. Contribution of Working Group III to the Fourth Assessment Report of the Intergovernmental Panel on Climate Change (Metz, B., Davidson, O. R., Bosch, P. R., Dave, R., Meyer, L.A., eds.), Cambridge University Press, Cambridge, United Kingdom and New York, NY, USA, 2007, $851 \mathrm{pp}$.

6. IPCC. IPCC Special Report on Carbon Dioxide Capture and Storage. Prepared by Working Group III of the Intergovernmental Panel on Climate Change (Metz, B., Davidson, O., de Coninck, H. C., Loos, M., Meyer, L. A., eds.). Cambridge University Press, Cambridge, United Kingdom and New York, NY, USA, 2005, 442 pp.

7. Sanna, A., Uibu, M., Caramanna, G., Kuusik, R., Maroto-Valer, M. M. A review of mineral carbonation technologies to sequester $\mathrm{CO}_{2}$. Chem. Soc. Rev., 2014, 43, 8049-8080.

8. Yamasaki, A. An overview of $\mathrm{CO}_{2}$ mitigation options for global warming-emphasizing $\mathrm{CO}_{2}$ sequestration options. J. Chem. Eng. Japan, 2003, 36(4), 361-375.

9. Oskierski, H. C., Dlugogorski, B. Z., Jacobsen, G. Sequestration of atmospheric $\mathrm{CO}_{2}$ in chrysotile mine tailings of the Woodsreef Asbestos Mine, Australia: Quantitative mineralogy, isotopic fingerprinting and carbonation rates. Chem. Geol., 2013, 358, 156-169.

10. Pronost, J., Beaudoin, G., Tremblay, J., Larachi, F., Duchesne, J., Hébert, R., Constantin, M. Carbon sequestration kinetic and storage capacity of ultramafic mining waste. Environ. Sci. Technol., 2011, 45(21), 9413-9420. 
11. Wilson, S. A., Harrison, A. L., Dipple, G. M., Power, I. M., Barker, S. L. L., Ulrich Mayer, K., Fallon, S. J., Raudsepp, M., Southam, G. Offsetting of $\mathrm{CO}_{2}$ emissions by air capture in mine tailings at the Mount Keith Nickel Mine, Western Australia: Rates, controls and prospects for carbon neutral mining. Int. J. Greenh. Gas Control, 2014, 25, 121-140.

12. Bobicki, E. R., Liu, Q., Xu, Z., Zeng, H. Carbon capture and storage using alkaline industrial wastes. Prog. Energy Combust. Sci., 2012, 38(2), 302-320.

13. Olajire, A. A. A review of mineral carbonation technology in sequestration of $\mathrm{CO}_{2}$. J. Pet. Sci. Eng., 2013, 109, 364-392.

14. Pan, S. Y., Chang, E. E., Chiang, P. C. $\mathrm{CO}_{2}$ capture by accelerated carbonation of alkaline wastes: A review on its principles and applications. Aerosol Air Qual. Res., 2012, 12(5), 770-791.

15. Montes-Hernandez, G., Pérez-López, R., Renard, F., Nieto, J.-M., Charlet, L. Mineral sequestration of $\mathrm{CO}_{2}$ by aqueous carbonation of coal combustion fly-ash. J. Hazard. Mater., 2009, 161(2-3), 1347-1354.

16. Statistics Estonia. Statistical Yearbook of Estonia 2016 (Põder, K., ed.). Tallinn, 2016.

17. Crippa, M., Oreggioni, G., Guizzardi, D., Muntean, M., Schaaf, E., Lo Vullo, E., Solazzo, E., Monforti-Ferrario, F., Olivier, J., Vignati, E. Fossil $\mathrm{CO}_{2}$ and $\mathrm{GHG}$ emissions of all world countries. Publications Office of the European Union, Luxembourg, 2019.

18. Eesti Energia. Annual Report 2019. Environmental Report. https://www. energia.ee/-/doc/8644186/ettevottest/aastaaruanne/pdf/EE_AA_2019_ENG.pdf (accessed 13 May 2020).

19. Elering. Estonian long-term power scenarios. Tallinn, 2014. https://elering. ee/sites/default/files/attachments/Estonian-Long-term-Energy-Scenarios.pdf (accessed 13 May 2020).

20. Ots, A. Oil Shale Fuel Combustion. Tallinna Raamatutrükikoda. Tallinn, 2006.

21. Mõtlep, R., Sild, T., Puura, E., Kirsimäe, K. Composition, diagenetic transformation and alkalinity potential of oil shale ash sediments. J. Hazard. Mater., 2010, 184(1-3), 567-573.

22. Konist, A., Maaten, B., Loo, L., Neshumayev, D., Pihu, T. Mineral sequestration of $\mathrm{CO}_{2}$ by carbonation of Ca-rich oil shale ash in natural conditions. Oil Shale, 2016, 33(3), 248-259.

23. Gavrilova, O., Randla, T., Vallner, L., Strandberg, M., Vilu, R. Life Cycle Analysis of the Estonian Oil Shale Industry. Estonian Fund for Nature, Tallinn University of Technology, Tallinn, 2005, $145 \mathrm{pp}$.

24. Loo, L., Konist, A., Neshumayev, D., Pihu, T., Maaten, B., Siirde, A. Ash and flue gas from oil shale oxy-fuel circulating fluidized bed combustion. Energies, 2018, 11(5), 1218.

25. Arro, H., Prikk, A., Pihu, T. Calculation of $\mathrm{CO}_{2}$ emission from CFB boilers of oil shale power plants. Oil Shale, 2006, 23(4), 356-365.

26. Shogenova, A., Shogenov, K., Pomeranceva, R., Nulle, I., Neele, F., Hendriks, C. Economic modelling of the capture-transport-sink scenario of industrial $\mathrm{CO}_{2}$ emissions: The Estonian-Latvian cross-border case study. Energy Procedia, 2011, 4, 2385-2392. 
27. Shogenova, A., Sliaupa, S., Vaher, R., Shogenov, K., Pomeranceva, R. The Baltic Basin: structure, properties of reservoir rocks, and capacity for geological storage of $\mathrm{CO}_{2}$. Est. J. Earth Sci., 2009, 58(4), 259-267.

28. Pihu, T., Konist, A., Puura, E., Liira, M., Kirsimäe, K. Properties and environmental impact of oil shale ash landfills. Oil Shale, 2019, 36(2), 257-270.

29. Leben, K., Mõtlep, R., Paaver, P., Konist, A., Pihu, T., Paiste, P., Heinmaa, I., Nurk, G., Anthony, E. J., Kirsimäe, K. Long-term mineral transformation of Ca-rich oil shale ash waste. Sci. Total Environ., 2019, 658, 1404-1415.

30. Uibu, M., Kuusik, R. Main physicochemical factors affecting the aqueous carbonation of oil shale ash. Miner. Eng., 2014, 59, 64-70.

31. Kuusik, R., Veskimäe, H., Kaljuvee, T., Parts, O. Carbon dioxide binding in the heterogeneous systems formed by combustion of oil shale. 1. Carbon dioxide binding at oil shale ash deposits. Oil Shale, 2001, 18(2), 109-122.

32. Uibu, M., Uus, M., Kuusik, R. $\mathrm{CO}_{2}$ mineral sequestration in oil-shale wastes from Estonian power production. J. Environ. Manage., 2009, 90(2), 1253-1260.

33. Pihu, T., Arro, H., Prikk, A., Rootamm, R., Konist, A., Kirsimäe, K., Liira, M., Mõtlep, R. Oil shale CFBC ash cementation properties in ash fields. Fuel, 2012, 93, 172-180.

34. Golubev, N. Solid oil shale heat carrier technology for oil shale retorting. Oil Shale, 2003, 20(3S), 324-332.

35. Bityukova, L., Mõtlep, R., Kirsimäe, K. Composition of oil shale ashes from pulverized firing and circulating fluidized-bed boiler in Narva Thermal Power Plants, Estonia. Oil Shale, 2010, 27(4), 339-353.

36. Liira, M., Kirsimäe, K., Kuusik, R., Mõtlep, R. Transformation of calcareous oil-shale circulating fluidized-bed combustion boiler ashes under wet conditions. Fuel, 2009, 88(4), 712-718.

37. Chen, J. J., Thomas, J. J., Taylor, H. F. W., Jennings, H. M. Solubility and structure of calcium silicate hydrate. Cem. Concr. Res., 2004, 34(9), 1499-1519.

38. O’Connor, W., Dahlin, D. C., Rush, G. E., Gerdemann, S. J., Penner, L. R., Nilsen, D. N. Aqueous Mineral Carbonation: Mineral Availability, Pretreatment, Reaction Parametrics, and Process Studies. DOE/ARC-TR-04-002, Albany Research Center, Albany, New York, 2005.

39. Magbitang, R. A., Lamorena, R. B. Carbonate formation on ophiolitic rocks at different $\mathrm{pH}$, salinity and particle size conditions in $\mathrm{CO}_{2}$-sparged suspensions. Int. J. Ind. Chem., 2016, 7, 359-367.

40. Turvey, C. C., Wilson, S. A., Hamilton, J. L., Tait, A. W., McCutcheon, J., Beinlich, A., Fallon, S. J., Dipple, G. M., Southam, G. Hydrotalcites and hydrated $\mathrm{Mg}$-carbonates as carbon sinks in serpentinite mineral wastes from the Woodsreef chrysotile mine, New South Wales, Australia: Controls on carbonate mineralogy and efficiency of $\mathrm{CO}_{2}$ air capture in mine tailings. Int. J. Greenh. Gas Control, 2018, 79, 38-60.

41. Nishikawa, T., Suzuki, K., Ito, S., Sato, K., Takebe, T. Decomposition of synthesized ettringite by carbonation. Cem. Concr. Res., 1992, 22(1), 6-14.

42. Hartshorn, S. A., Sharp, J. H., Swamy, R. N. Thaumasite formation in Portland-limestone cement pastes - A cause of deterioration of Portland cement and related sub- 
stances in the presence of sulphates. Cem. Concr. Res., 1999, 29(8), 1331-1340.

43. Zhou, Q., Hill, J., Byars, E. A., Cripps, J. C., Lynsdale, C. J., Sharp, J. H. The role of pH in thaumasite sulfate attack. Cem. Concr. Res., 2006, 36(1), 160-170.

44. Kuusik, R., Paat, A., Veskimäe, H., Uibu, M. Transformations in oil shale ash at wet deposition. Oil Shale, 2004, 21(1), 27-42.

45. Kuusik, R., Veskimäe, H., Uibu, M. Carbon dioxide binding in the heterogeneous systems formed at combustion of oil shale 3. Transformations in the system suspension of ash - flue gases. Oil Shale, 2002, 19(3), 277-288.

46. Trikkel, A., Keelmann, M., Kaljuvee, T., Kuusik, R. $\mathrm{CO}_{2}$ and $\mathrm{SO}_{2}$ uptake by oil shale ashes: Effect of pre-treatment on kinetics. J. Therm. Anal. Calorim., 2010, 99(3), 763-769.

47. Uibu, M., Velts, O., Kuusik, R. Developments in $\mathrm{CO}_{2}$ mineral carbonation of oil shale ash. J. Hazard. Mater., 2010, 174(1-3), 209-214.

48. Uibu, M., Kuusik, R., Veskimäe, H. Seasonal binding of atmospheric $\mathrm{CO}_{2}$ by oil shale ash. Oil Shale, 2008, 25(2), 254-266.

49. Velts, O., Uibu, M., Kallas, J., Kuusik, R. $\mathrm{CO}_{2}$ mineral trapping: Modeling of calcium carbonate precipitation in a semi-batch reactor. Energy Procedia, 2011, 4, 771-778.

50. Kuusik, R., Uibu, M., Kirsimäe, K. Characterization of oil shale ashes formed at industrial scale boilers. Oil Shale, 2005, 22(4S), 407-419.

51. Konist, A., Pihu, T., Neshumayev, D., Siirde, A. Oil shale pulverized firing: Boiler efficiency, ash balance and flue gas composition. Oil Shale, 2013, 30(1), 6-18.

52. Aguilera, J., Martínez-Ramírez, S., Pajares-Colomo, I., Blanco-Varela, M. T. Formation of thaumasite in carbonated mortars. Cem. Concr. Compos., 2003, 25(8), 991-996.

53. Dyer, T. Concrete Durability. CRC Press, 2014.

54. Arro, H., Prikk, A., Pihu, T. Reducing the environmental impact of Baltic Power Plant ash fields. Oil Shale, 2003, 20(3S), 375-382.

55. Hyvert, N., Sellier, A., Duprat, F., Rougeau, P., Francisco, P. Dependency of C-S-H carbonation rate on $\mathrm{CO}_{2}$ pressure to explain transition from accelerated tests to natural carbonation. Cem. Concr. Res., 2010, 40(11), 1582-1589.

56. Suzuki, K., Nishikawa, T., Ito, S. Formation and carbonation of C-S-H in water. Cem. Concr. Res., 1985, 15(2), 213-224.

57. Wu, B., Ye, G. Carbonation mechanism of different kinds of C-S-H: rate and products. In Proceedings of the International RILEM Conference Materials, Systems and Structures in Civil Engineering 2016, Segment on Concrete with Supplementary Cementitious Materials, 22-24 August 2016, Technical University of Denmark, Lyngby, Denmark (Jensen, O. M., Kovler, K., De Belie, N., eds.), RILEM, 2016, 263-272. 
Supplementary Table

\begin{tabular}{|c|c|c|c|c|c|c|c|c|c|c|c|}
\hline \multicolumn{3}{|c|}{ Eesti Power Plant drill-core 2} & \multicolumn{9}{|c|}{ Mineral composition, wt $\%$} \\
\hline $\begin{array}{l}\text { N } \\
\frac{\tilde{E}}{0} \\
\frac{0}{0}\end{array}$ & Dept & ral, m & 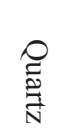 & $\begin{array}{l}\pi \\
\frac{\pi}{\overrightarrow{0}} \\
\frac{0}{2} \\
\frac{2}{0}\end{array}$ & 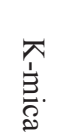 & 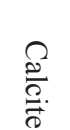 & 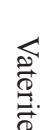 & 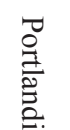 & 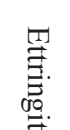 & 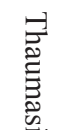 & $\underset{\substack{1 \\
i}}{\stackrel{P}{1}}$ \\
\hline 1 & 0.3 & 0.6 & 11.8 & 8.7 & 5.3 & 15.0 & 0.7 & 0.0 & 7.7 & 3.0 & 25.4 \\
\hline 2 & 0.6 & 1 & 12.3 & 5.7 & 3.3 & 6.6 & 0.6 & 1.3 & 11.9 & 3.2 & 27.0 \\
\hline 3 & 1 & 1.4 & 5.2 & 3.0 & 4.2 & 5.6 & 0.4 & 11.7 & 7.5 & 6.1 & 26.8 \\
\hline 4 & 1.4 & 1.7 & 14.4 & 10.4 & 9.9 & 12.2 & 0.4 & 0.0 & 0.2 & 1.0 & 27.5 \\
\hline 5 & 1.7 & 2 & 7.1 & 3.1 & 5.9 & 3.4 & 0.4 & 8.5 & 0.3 & 1.0 & 37.6 \\
\hline 6 & 2 & 2.5 & 7.0 & 3.6 & 4.7 & 3.2 & 0.3 & 0.9 & 12.4 & 11.1 & 36.0 \\
\hline 7 & 2.5 & 2.9 & 3.4 & 3.0 & 10.4 & 0.3 & 0.4 & 12.6 & 1.8 & 6.5 & 27.0 \\
\hline 8 & 2.9 & 3.3 & 3.2 & 2.6 & 8.6 & 2.3 & 0.6 & 13.2 & 3.0 & 11.1 & 20.7 \\
\hline 9 & 3.3 & 3.8 & 4.7 & 2.4 & 8.5 & 1.4 & 0.2 & 6.5 & 3.0 & 8.3 & 34.7 \\
\hline 10 & 3.8 & 4.3 & 7.2 & 4.2 & 5.9 & 3.3 & 0.8 & 0.7 & 1.3 & 15.8 & 34.1 \\
\hline 11 & 4.3 & 4.8 & 2.0 & 4.0 & 0.0 & 0.7 & 0.4 & 21.4 & 0.0 & 2.0 & 29.4 \\
\hline 12 & 4.8 & 5.4 & 7.0 & 3.7 & 0.0 & 2.9 & 0.4 & 0.9 & 0.0 & 10.9 & 48.8 \\
\hline 13 & 5.4 & 6 & 7.0 & 5.1 & 0.0 & 3.1 & 0.5 & 3.4 & 0.0 & 2.8 & 53.0 \\
\hline 14 & 6 & 6.5 & 6.5 & 4.9 & 0.0 & 2.9 & 0.3 & 9.1 & 0.0 & 14.2 & 30.4 \\
\hline 15 & 6.5 & 7.1 & 4.3 & 3.9 & 0.0 & 7.6 & 0.2 & 10.4 & 0.0 & 2.2 & 38.7 \\
\hline 16 & 7.1 & 7.6 & 3.3 & 2.6 & 0.0 & 5.8 & 0.1 & 3.8 & 0.0 & 9.2 & 41.0 \\
\hline 17 & 7.6 & 8.1 & 3.2 & 2.3 & 0.0 & 4.5 & 0.6 & 3.1 & 0.0 & 4.2 & 44.9 \\
\hline 18 & 8.1 & 8.5 & 6.4 & 4.1 & 0.0 & 7.9 & 1.0 & 0.0 & 0.0 & 0.9 & 51.4 \\
\hline 19 & 8.5 & 9 & 5.6 & 4.7 & 0.0 & 8.5 & 0.6 & 0.0 & 0.0 & 14.8 & 38.5 \\
\hline 20 & 9 & 9.5 & 1.7 & 1.5 & 0.0 & 2.9 & 0.4 & 1.6 & 0.0 & 2.8 & 50.2 \\
\hline 21 & 9.5 & 10.1 & 2.9 & 1.5 & 0.0 & 6.3 & 0.6 & 1.6 & 0.0 & 3.4 & 45.0 \\
\hline 22 & 10.1 & 10.6 & 3.9 & 2.2 & 0.0 & 6.1 & 0.7 & 1.7 & 0.0 & 7.8 & 43.0 \\
\hline 23 & 10.6 & 11.2 & 3.7 & 3.4 & 0.0 & 6.9 & 0.4 & 0.0 & 0.0 & 14.0 & 41.5 \\
\hline
\end{tabular}




\section{Supplementary Table (continuation)}

\begin{tabular}{|c|c|c|c|c|c|c|c|c|c|c|c|}
\hline \multicolumn{3}{|c|}{ Eesti Power Plant drill-core 2} & \multicolumn{9}{|c|}{ Mineral composition, wt $\%$} \\
\hline 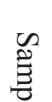 & \multicolumn{2}{|c|}{ Depth interval, $\mathrm{m}$} & & $\begin{array}{l}\mathbb{\pi} \\
\frac{1}{0} \\
\frac{0}{2}\end{array}$ & $\begin{array}{l}\text { त्र } \\
\text { E. }\end{array}$ & $\frac{\mathscr{0}}{3}$. & 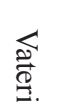 & 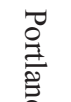 & $\begin{array}{l}\text { 荘. } \\
\text { E. }\end{array}$ & 突 & $\stackrel{P}{P}_{1}^{P}$ \\
\hline 24 & 11.2 & 11.7 & 8.8 & 4.0 & 0.0 & 4.8 & 0.7 & 0.0 & 0.0 & 15.6 & 39.5 \\
\hline 25 & 11.7 & 12.1 & 15.7 & 13.3 & 0.0 & 14.4 & 0.8 & 0.2 & 23.7 & 2.1 & 11.7 \\
\hline 26 & 12.1 & 12.6 & 14.8 & 11.5 & 0.0 & 14.4 & 0.4 & 0.1 & 0.0 & 1.5 & 37.3 \\
\hline 27 & 12.6 & 13.1 & 11.6 & 10.6 & 0.0 & 17.1 & 0.1 & 0.2 & 12.8 & 1.7 & 25.8 \\
\hline 28 & 13.1 & 13.6 & 12.7 & 11.0 & 0.0 & 6.2 & 0.7 & 0.1 & 5.0 & 15.8 & 25.9 \\
\hline 29 & 13.6 & 14.1 & 13.6 & 11.5 & 0.0 & 6.3 & 0.7 & 0.0 & 5.7 & 16.8 & 22.5 \\
\hline 30 & 14.1 & 14.7 & 17.1 & 14.4 & 8.9 & 14.3 & 0.3 & 0.0 & 2.1 & 8.5 & 11.5 \\
\hline 31 & 14.7 & 15.2 & 11.4 & 9.4 & 5.9 & 6.1 & 0.9 & 0.0 & 7.4 & 19.5 & 18.6 \\
\hline 32 & 15.2 & 15.8 & 10.9 & 6.9 & 4.1 & 17.1 & 0.7 & 0.0 & 7.7 & 11.8 & 22.0 \\
\hline 33 & 15.8 & 16.3 & 15.2 & 10.3 & 6.5 & 12.3 & 1.5 & 0.0 & 5.7 & 7.4 & 25.3 \\
\hline 34 & 16.3 & 16.8 & 8.9 & 6.1 & 6.5 & 4.1 & 0.8 & 0.1 & 10.4 & 18.4 & 23.7 \\
\hline 35 & 16.8 & 17.2 & 6.2 & 4.5 & 1.4 & 1.8 & 1.4 & 0.2 & 9.8 & 19.8 & 31.6 \\
\hline 36 & 17.2 & 17.7 & 8.5 & 5.6 & 2.7 & 12.8 & 0.4 & 0.7 & 1.7 & 3.0 & 38.3 \\
\hline 37 & 17.7 & 18.2 & 4.3 & 1.9 & 0.4 & 21.1 & 0.4 & 0.1 & 14.8 & 15.9 & 18.1 \\
\hline 38 & 18.2 & 18.7 & 2.7 & 1.5 & 3.3 & 25.5 & 0.6 & 0.3 & 18.7 & 11.3 & 18.6 \\
\hline 39 & 18.7 & 19.2 & 1.5 & 0.8 & 2.1 & 16.1 & 0.0 & 0.5 & 16.4 & 32.2 & 9.0 \\
\hline 40 & 19.2 & 19.7 & 1.2 & 0.8 & 0.0 & 0.3 & 0.4 & 7.5 & 21.5 & 17.1 & 30.2 \\
\hline 41 & 19.7 & 20.3 & 2.0 & 0.4 & 0.0 & 2.2 & 0.3 & 8.0 & 13.8 & 20.2 & 26.4 \\
\hline 42 & 20.3 & 20.9 & 3.2 & 3.5 & 0.0 & 0.2 & 0.3 & 18.1 & 1.3 & 0.7 & 43.3 \\
\hline 43 & 20.9 & 21.5 & 2.0 & 1.4 & 0.0 & 1.4 & 0.0 & 12.0 & 19.3 & 22.7 & 14.0 \\
\hline 44 & 21.5 & 22 & 1.6 & 1.2 & 0.0 & 6.1 & 0.4 & 17.0 & 0.0 & 1.6 & 32.8 \\
\hline 45 & 22 & 22.8 & 2.6 & 1.6 & 0.0 & 3.2 & 0.4 & 17.1 & 3.1 & 0.8 & 32.1 \\
\hline 46 & 22.8 & 24 & 2.5 & 2.3 & 0.0 & 2.0 & 0.4 & 18.4 & 0.1 & 1.0 & 43.2 \\
\hline 47 & 24 & 24.6 & 5.1 & 2.9 & 0.0 & 1.7 & 0.7 & 0.4 & 0.0 & 0.7 & 67.3 \\
\hline
\end{tabular}




\section{Supplementary Table (continuation)}

\begin{tabular}{|c|c|c|c|c|c|c|c|c|c|c|c|}
\hline \multicolumn{3}{|c|}{ Eesti Power Plant drill-core 2} & \multicolumn{9}{|c|}{ Mineral composition, wt\% } \\
\hline 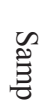 & \multicolumn{2}{|c|}{ Depth interval, m } & $\underset{\mathscr{E}}{\widetilde{E}}$ & $\begin{array}{l}\mathbb{\lambda} \\
\frac{\overrightarrow{0}}{2} \\
\frac{0}{\infty}\end{array}$ & 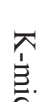 & $\frac{\tilde{0}}{3}$. & 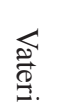 & 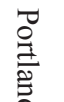 & $\begin{array}{l}\text { T) } \\
\text { 䓌. }\end{array}$ & 胥 & $\frac{1}{B}$ \\
\hline 48 & 24.6 & 25.1 & 2.4 & 2.7 & 0.0 & 1.2 & 0.4 & 8.2 & 1.8 & 1.8 & 44.6 \\
\hline 49 & 25.1 & 25.7 & 1.8 & 2.1 & 0.0 & 1.2 & 0.7 & 1.6 & 1.1 & 2.0 & 64.3 \\
\hline 50 & 25.7 & 26.3 & 4.5 & 2.8 & 0.0 & 8.7 & 0.9 & 0.1 & 1.0 & 0.9 & 55.5 \\
\hline 51 & 26.3 & 27.2 & 5.7 & 3.1 & 0.0 & 5.2 & 0.5 & 5.8 & 0.6 & 0.7 & 53.2 \\
\hline 52 & 27.2 & 27.7 & 4.2 & 2.6 & 0.0 & 7.2 & 0.6 & 1.9 & 1.0 & 0.2 & 50.4 \\
\hline 53 & 27.7 & 28.8 & 9.5 & 6.2 & 0.0 & 10.4 & 0.6 & 0.0 & 0.3 & 0.8 & 53.0 \\
\hline 54 & 28.8 & 29.3 & 5.7 & 1.1 & 0.0 & 5.3 & 0.7 & 1.1 & 0.0 & 1.5 & 54.5 \\
\hline 55 & 29.3 & 29.9 & 5.3 & 1.2 & 0.0 & 5.1 & 0.6 & 0.1 & 0.3 & 1.3 & 57.7 \\
\hline 56 & 29.9 & 30.5 & 2.0 & 3.7 & 0.0 & 0.3 & 0.3 & 14.8 & 1.0 & 0.2 & 35.2 \\
\hline 57 & 30.5 & 30.8 & 2.4 & 2.4 & 0.0 & 0.3 & 0.5 & 14.8 & 0.5 & 0.2 & 47.6 \\
\hline 58 & 30.8 & 31.3 & 1.3 & 1.6 & 0.0 & 0.5 & 0.9 & 14.0 & 0.6 & 1.2 & 41.8 \\
\hline 59 & 31.3 & 31.8 & 1.7 & 2.7 & 0.0 & 0.0 & 0.5 & 10.6 & 3.0 & 1.5 & 53.1 \\
\hline 60 & 31.8 & 32.4 & 1.3 & 2.5 & 0.0 & 0.2 & 0.6 & 13.8 & 0.4 & 1.4 & 51.6 \\
\hline 61 & 32.4 & 32.8 & 3.1 & 2.4 & 0.0 & 0.3 & 0.8 & 9.0 & 1.9 & 0.7 & 50.2 \\
\hline 62 & 32.8 & 33.2 & 3.9 & 2.4 & 0.0 & 2.2 & 0.9 & 2.5 & 0.3 & 0.0 & 63.1 \\
\hline 63 & 33.2 & 33.6 & 4.9 & 3.5 & 0.0 & 3.1 & 0.9 & 0.1 & 0.7 & 0.3 & 64.6 \\
\hline 64 & 33.6 & 34 & 4.6 & 3.7 & 0.0 & 5.7 & 1.1 & 0.0 & 0.5 & 0.0 & 61.7 \\
\hline 65 & 34 & 34.6 & 5.1 & 3.2 & 0.0 & 2.7 & 1.0 & 0.0 & 0.2 & 1.6 & 63.6 \\
\hline 66 & 34.6 & 35.3 & 3.2 & 2.3 & 0.0 & 5.1 & 0.6 & 0.0 & 11.6 & 3.0 & 47.2 \\
\hline 67 & 35.3 & 36.1 & 3.0 & 1.8 & 1.6 & 5.1 & 0.5 & 0.0 & 11.0 & 2.6 & 51.0 \\
\hline 68 & 36.1 & 36.8 & 3.8 & 3.7 & 0.0 & 2.5 & 1.0 & 0.0 & 0.1 & 1.7 & 66.2 \\
\hline 69 & 36.8 & 37.1 & 2.7 & 3.6 & 0.0 & 16.4 & 0.4 & 0.6 & 0.5 & 1.2 & 55.0 \\
\hline
\end{tabular}




\section{Supplementary Table (continuation)}

\begin{tabular}{|c|c|c|c|c|c|c|c|c|c|c|c|}
\hline \multicolumn{3}{|c|}{ Balti Power Plant drill-core 5} & \multicolumn{9}{|c|}{ Mineral composition, wt $\%$} \\
\hline 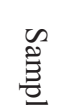 & Depth & val, $\mathrm{m}$ & 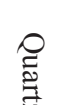 & $\begin{array}{l}\mathbb{\pi} \\
\frac{1}{0} \\
\frac{\overrightarrow{0}}{2}\end{array}$ & $\begin{array}{l}\text { त्र } \\
\stackrel{1}{\Xi} .\end{array}$ & $\stackrel{\Omega}{\stackrel{0}{\varrho}}$ & $\begin{array}{l}\text { त्ञ } \\
\text { g. }\end{array}$ & $\begin{array}{l}\overrightarrow{0} \\
\stackrel{2}{0} \\
\hat{\tilde{D}}\end{array}$ & 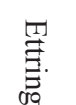 & $\begin{array}{l}\text { 귤 } \\
\stackrel{0}{\Xi}\end{array}$ & $\underbrace{P}_{1}$ \\
\hline 1 & 1.3 & 1.5 & 4.7 & 3.7 & 3.5 & 6.0 & 0.6 & 17.1 & 8.3 & 2.3 & 23.7 \\
\hline 2 & 1.5 & 1.8 & 8.7 & 5.1 & 4.7 & 18.0 & 0.6 & 1.4 & 14.4 & 1.1 & 25.7 \\
\hline 3 & 1.8 & 2.1 & 9.0 & 3.5 & 2.6 & 11.9 & 0.7 & 0.0 & 15.2 & 0.8 & 38.7 \\
\hline 4 & 2.1 & 2.5 & 6.7 & 3.2 & 6.3 & 5.9 & 0.5 & 8.5 & 5.9 & 0.5 & 32.5 \\
\hline 5 & 2.5 & 2.7 & 7.9 & 5.4 & 4.3 & 9.4 & 0.6 & 6.8 & 4.3 & 0.2 & 33.4 \\
\hline 6 & 2.7 & 2.85 & 12.9 & 5.7 & 2.2 & 12.9 & 0.4 & 0.0 & 13.0 & 0.7 & 32.0 \\
\hline 7 & 2.85 & 3.2 & 12.5 & 6.6 & 2.1 & 12.4 & 1.9 & 0.0 & 12.3 & 0.8 & 36.0 \\
\hline 8 & 3.2 & 3.7 & 11.0 & 5.7 & 2.9 & 13.7 & 1.3 & 0.5 & 14.2 & 0.7 & 31.3 \\
\hline 9 & 3.7 & 4.2 & 14.7 & 8.5 & 8.8 & 17.9 & 0.4 & 0.0 & 9.6 & 2.1 & 20.6 \\
\hline 10 & 4.2 & 4.6 & 14.8 & 10.9 & 8.8 & 16.6 & 0.7 & 0.0 & 13.1 & 3.2 & 13.8 \\
\hline 11 & 4.6 & 4.8 & 14.1 & 11.2 & 8.4 & 17.2 & 0.7 & 0.0 & 12.3 & 3.3 & 12.8 \\
\hline 12 & 4.8 & 6.4 & 14.1 & 12.9 & 8.8 & 16.5 & 0.9 & 0.0 & 9.5 & 3.6 & 15.1 \\
\hline 13 & 6.4 & 7.25 & 15.6 & 11.6 & 7.8 & 13.2 & 1.9 & 0.0 & 10.7 & 2.6 & 12.8 \\
\hline 14 & 7.25 & 8.2 & 13.2 & 8.9 & 3.8 & 22.8 & 1.2 & 0.8 & 14.1 & 1.6 & 13.1 \\
\hline 15 & 8.2 & 9 & 14.3 & 10.3 & 8.1 & 22.7 & 0.7 & 0.0 & 14.8 & 2.5 & 9.1 \\
\hline 16 & 9 & 10 & 14.5 & 10.6 & 5.8 & 27.8 & 0.7 & 0.6 & 8.4 & 2.3 & 10.8 \\
\hline 17 & 10 & 10.9 & 17.0 & 13.4 & 9.8 & 26.4 & 0.5 & 0.0 & 6.6 & 1.2 & 7.2 \\
\hline 18 & 10.9 & 11.5 & 19.1 & 17.2 & 13.9 & 21.8 & 0.0 & 0.0 & 2.9 & 1.3 & 7.1 \\
\hline 19 & 11.5 & 11.85 & 18.4 & 14.7 & 11.2 & 29.0 & 0.0 & 0.0 & 2.6 & 0.6 & 5.3 \\
\hline 20 & 11.85 & 12.7 & 16.9 & 14.8 & 10.3 & 27.7 & 0.0 & 0.0 & 2.3 & 0.6 & 9.2 \\
\hline 21 & 12.7 & 13.3 & 20.1 & 17.0 & 14.5 & 24.6 & 0.0 & 0.0 & 1.4 & 0.6 & 4.8 \\
\hline 22 & 13.3 & 13.7 & 17.2 & 15.2 & 13.2 & 29.3 & 0.3 & 0.0 & 1.7 & 0.7 & 5.7 \\
\hline 23 & 13.7 & 14.35 & 18.1 & 15.5 & 12.6 & 26.5 & 0.0 & 0.0 & 2.2 & 0.7 & 7.7 \\
\hline
\end{tabular}




\section{Supplementary Table (continuation)}

\begin{tabular}{|c|c|c|c|c|c|c|c|c|c|c|c|}
\hline \multicolumn{3}{|c|}{ Balti Power Plant drill-core 5} & \multicolumn{9}{|c|}{ Mineral composition, wt $\%$} \\
\hline 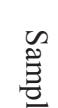 & Depth & val, m & 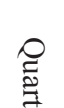 & $\begin{array}{l}\mathbb{T} \\
\overrightarrow{0} \\
\frac{\vec{d}}{2}\end{array}$ & $\begin{array}{l}\text { त. } \\
\hat{3}\end{array}$ & $\begin{array}{l}\stackrel{\Omega}{2} \\
\stackrel{0}{\Omega}\end{array}$ & $\begin{array}{l}\text { त्ञ } \\
\text { 莺. }\end{array}$ & $\begin{array}{l}\overrightarrow{0} \\
\stackrel{0}{=} \\
\stackrel{0}{0}\end{array}$ & 罣. & 雨 & $\stackrel{P}{P}_{1}^{R}$ \\
\hline 24 & 14.35 & 14.9 & 16.2 & 13.9 & 11.9 & 27.1 & 0.3 & 0.0 & 2.5 & 0.8 & 9.9 \\
\hline 25 & 14.9 & 15.5 & 15.3 & 12.8 & 10.9 & 32.4 & 0.0 & 0.0 & 1.8 & 0.7 & 7.2 \\
\hline 26 & 15.5 & 16.1 & 16.2 & 14.0 & 12.7 & 27.7 & 0.0 & 0.0 & 1.7 & 0.9 & 7.8 \\
\hline 27 & 16.1 & 16.6 & 16.0 & 15.3 & 12.0 & 30.0 & 0.0 & 0.0 & 1.3 & 1.0 & 6.8 \\
\hline 28 & 16.6 & 17.3 & 17.4 & 12.8 & 10.5 & 27.4 & 0.3 & 0.0 & 2.4 & 1.3 & 10.0 \\
\hline 29 & 17.3 & 18 & 18.2 & 16.1 & 14.5 & 25.4 & 0.4 & 0.0 & 1.3 & 0.6 & 6.5 \\
\hline 30 & 18 & 19.9 & 6.3 & 3.2 & 1.5 & 36.3 & 0.4 & 0.0 & 3.4 & 6.8 & 24.9 \\
\hline 31 & 19.9 & 22.25 & 10.0 & 4.3 & 5.8 & 11.4 & 4.3 & 0.0 & 7.3 & 8.7 & 32.1 \\
\hline 32 & 22.25 & 24.5 & 7.1 & 3.9 & 3.3 & 6.1 & 19.7 & 2.4 & 2.3 & 2.6 & 31.0 \\
\hline 33 & 24.5 & 26 & 8.9 & 3.3 & 5.2 & 12.0 & 8.4 & 0.3 & 2.1 & 1.3 & 39.7 \\
\hline 34 & 26 & 26.4 & 12.6 & 4.1 & 4.7 & 11.9 & 5.3 & 0.0 & 4.1 & 4.0 & 39.8 \\
\hline 35 & 26.4 & 27.3 & 11.8 & 5.2 & 5.8 & 15.5 & 12.4 & 0.0 & 2.8 & 5.1 & 20.0 \\
\hline 36 & 27.3 & 28.15 & 8.4 & 3.3 & 3.9 & 7.1 & 19.2 & 0.0 & 6.3 & 6.7 & 27.3 \\
\hline 37 & 28.15 & 29.1 & 5.2 & 2.3 & 1.5 & 5.7 & 28.5 & 0.0 & 3.1 & 1.9 & 32.4 \\
\hline 38 & 29.1 & 29.35 & 7.2 & 2.6 & 2.3 & 10.9 & 21.3 & 0.0 & 2.7 & 1.4 & 34.8 \\
\hline 39 & 29.35 & 30.45 & 4.9 & 3.3 & 1.2 & 6.4 & 31.1 & 0.0 & 1.1 & 0.8 & 29.2 \\
\hline 40 & 30.45 & 31.05 & 7.0 & 3.5 & 1.4 & 8.4 & 26.6 & 0.0 & 1.3 & 0.8 & 31.1 \\
\hline 41 & 31.05 & 31.95 & 7.4 & 3.8 & 1.2 & 14.8 & 22.4 & 0.0 & 2.6 & 1.7 & 23.5 \\
\hline 42 & 31.95 & 32 & 6.8 & 3.5 & 2.3 & 8.9 & 29.4 & 0.0 & 2.1 & 1.1 & 24.3 \\
\hline
\end{tabular}




\section{Supplementary Table (continuation)}

\begin{tabular}{|c|c|c|c|c|c|c|c|c|c|c|c|}
\hline \multicolumn{3}{|c|}{ Balti Power Plant drill-core 6} & \multicolumn{9}{|c|}{ Mineral composition, wt $\%$} \\
\hline $\begin{array}{l}\mathscr{U} \\
\tilde{\tilde{E}} \\
\tilde{E}\end{array}$ & Depth & val, $\mathrm{m}$ & 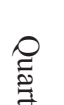 & $\begin{array}{l}\frac{\pi}{\lambda} \\
\frac{\vec{c}}{2} \\
\frac{2}{2}\end{array}$ & $\begin{array}{l}\text { 公 } \\
\text { E. }\end{array}$ & $\stackrel{\Omega}{0}$ & 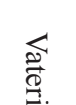 & $\begin{array}{l}\overrightarrow{0} \\
\stackrel{0}{*}\end{array}$ & 置. & 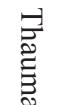 & $\stackrel{P}{P}_{1}^{P}$ \\
\hline 1 & 0.3 & 0.65 & 4 & 2.4 & 1.4 & 12.5 & 10.2 & 12.1 & 4.1 & 6 & 22.6 \\
\hline 2 & 0.65 & 1.65 & 5.2 & 1.8 & 4.1 & 3.5 & 16.9 & 6.9 & 2.9 & 5 & 30 \\
\hline 3 & 1.65 & 3.25 & 6.3 & 2.6 & 2.3 & 11.9 & 11.5 & 7.3 & 2.4 & 5 & 22.7 \\
\hline 4 & 3.25 & 4 & 7.5 & 1.9 & 2.5 & 12.3 & 12.2 & 3.9 & 4.5 & 3.6 & 28 \\
\hline 5 & 4 & 5.2 & 6.4 & 2.6 & 1.2 & 12.9 & 12.4 & 6.4 & 3.9 & 2.9 & 29.5 \\
\hline 6 & 5.2 & 6.15 & 6.5 & 2 & 1.6 & 13.4 & 13.9 & 8.7 & 3.6 & 2.4 & 25.3 \\
\hline 7 & 6.15 & 6.85 & 6.5 & 2.1 & 2.3 & 9.3 & 15.6 & 1.6 & 4 & 3.6 & 32.1 \\
\hline 8 & 6.85 & 7.7 & 6.7 & 2.3 & 1.8 & 8.4 & 19.9 & 2.3 & 3.2 & 3.5 & 29.1 \\
\hline 9 & 7.7 & 8.75 & 7.8 & 2.3 & 1.8 & 8.9 & 16.4 & 1.7 & 5.2 & 2.4 & 34 \\
\hline 10 & 8.75 & 9.45 & 4.4 & 2.2 & 1.4 & 11.5 & 12.8 & 9.6 & 3.9 & 2.8 & 28.4 \\
\hline 11 & 9.45 & 10.45 & 6.2 & 2.3 & 2.6 & 12.3 & 9.1 & 6.2 & 4.2 & 3.4 & 32.1 \\
\hline 12 & 10.45 & 11.35 & 6 & 2.6 & 2.2 & 15.5 & 10.7 & 3.7 & 4.8 & 3.9 & 30.2 \\
\hline 13 & 11.35 & 12.35 & 9.5 & 3.2 & 0.9 & 7.1 & 15.9 & 0 & 5.8 & 6.5 & 33.7 \\
\hline 14 & 12.35 & 12.65 & 4.7 & 3.1 & 1.4 & 6.4 & 21.6 & 5.6 & 5.5 & 6.3 & 24.1 \\
\hline 15 & 12.65 & 13.25 & 5.6 & 4.8 & 3.2 & 5.9 & 1.7 & 8.2 & 9.2 & 2.7 & 31.4 \\
\hline 16 & 13.25 & 14.2 & 5.4 & 3.7 & 1.2 & 10.3 & 15 & 5.6 & 5.1 & 4.8 & 25.5 \\
\hline 17 & 14.2 & 15.15 & 5.2 & 4 & 1.2 & 13 & 13.1 & 9.3 & 2.8 & 1.2 & 25.9 \\
\hline 18 & 15.15 & 16.1 & 5.5 & 4.4 & 3.4 & 7.5 & 2.3 & 6.9 & 6.2 & 5.7 & 31.7 \\
\hline 19 & 16.1 & 16.75 & 5.9 & 5 & 2.3 & 9.1 & 1.2 & 8.3 & 5.7 & 8.4 & 29.4 \\
\hline 20 & 16.75 & 17.75 & 4.5 & 5.4 & 2.2 & 7.2 & 2.1 & 10.7 & 6.8 & 0.7 & 29.4 \\
\hline 21 & 17.75 & 18.65 & 5.2 & 3.5 & 3.1 & 7.7 & 3 & 8.6 & 4 & 3.3 & 32.8 \\
\hline 22 & 18.65 & 19.65 & 6.2 & 4.9 & 5 & 8.5 & 3.4 & 7.2 & 3.2 & 2.6 & 30.2 \\
\hline 23 & 19.65 & 20.65 & 3.8 & 4.1 & 2.5 & 6.5 & 4.7 & 10.9 & 7.2 & 0.7 & 32.6 \\
\hline 24 & 20.65 & 21.65 & 5.7 & 4.3 & 3 & 10.8 & 2.1 & 3.7 & 2.9 & 2.8 & 41.7 \\
\hline 25 & 21.65 & 23.8 & 4.6 & 4.7 & 2.9 & 7.8 & 5.1 & 6.6 & 3.6 & 3.2 & 35.7 \\
\hline 26 & 23.8 & 24.8 & 5.3 & 3.1 & 4.8 & 8 & 1.3 & 0.9 & 7.6 & 5.8 & 40.4 \\
\hline 27 & 24.8 & 25.8 & 6 & 4.3 & 5.3 & 6.6 & 1.2 & 3.8 & 2.1 & 1.9 & 40 \\
\hline 28 & 25.8 & 26 & 8.8 & 2.9 & 6.4 & 6.2 & 3.3 & 0 & 10.2 & 8.3 & 39.7 \\
\hline
\end{tabular}

